ISSN 2078-6441. Вісник Львівського університету. Серія географічна. 2013. Випуск 42. С. 94-105. Visnyk of the Lviv University. Series Geography. 2013. Issue 42. P. 94-105.

543.3 .628 .16

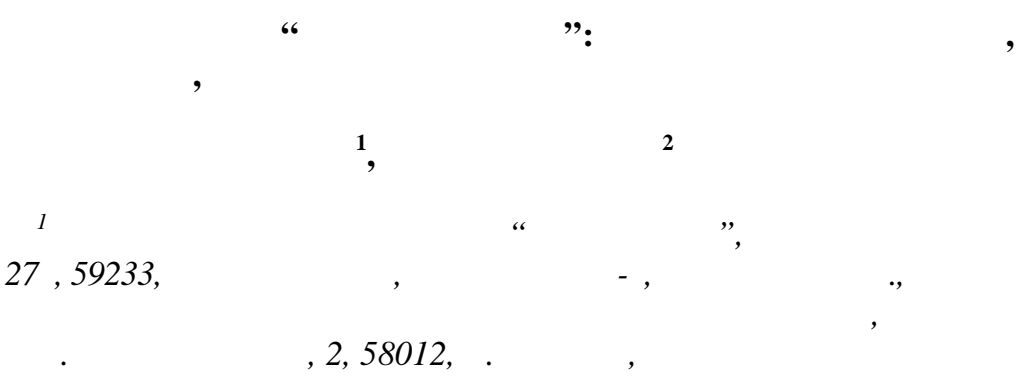

ивчено різном нітність джерел мінер льних вод н території “ ижницький”. ро н лізов но ретроспективні спекти дослідження цілющих підземних вод н території ціон льного природного п рку. изн чено, що джерел мінер льних вод розт шов ні у зон х регульов ної т ст ціон рної рекре ції, т кож господ рській зоні, що потребує розвитку туристичної інфр структури т посилення їхнього курортно-рекре ційного використ ння.

лючові слов : джерел мінер льних вод, ціон льний природний п рк, курортнорекре ційне використ ння мінер льних вод.

інер льні джерел - це н дзвич йний д р природи, оскільки вод , як н дходить н поверхню $з$ підземних н др, б г то століть бо і тисячоліть тому пройшл крізь ущелини різних ш рів породи, зб г чуючись вуглекислотою, солями т іншими хімічними елемент ми.

хідні обл сті кр їни з б г тством і різном нітністю мінер льних вод посід ють провідне місце не тільки в кр їні, й у вропі. йбільше відомими с н торнокурортними місцевостями з хідного регіону є курортополіс руск вець, м. оршин, м. хідниця ( ьвівськ обл.) т с. русниця ( ернівецьк обл.).

території ціон льного природного п рку ( ) “"ижницький” є дев’ять мінер льних джерел, які в поєдн нні з чудовими природними рекре ційними умов ми місцевості створюють н дзвич йно сприятливі передумови, для широкого розвитку всіх видів оздоровлення [1].

н чний внесок у вивчення мінер льних вод н території “ ижницький” і обгрунтув ння необхідності іх використ ння для б льнеологічних потреб зробив . пшин 1965 р. [5, 3]. ерші дослідження проводили в 1980-1983 pp. н терен х ижниччини ( ернівецьк обл.). ернівецьк комплексн гідрологічн п ртія ьвівської геологорозвідув льної експедиції провел розшукові роботи мінер льних вод типу “н фтуся" т інших типів, б льнеологічну оцінку яких викон в деський н уково-дослідний інститут медре біліт ції т курортології [1, 4].

ході розшуків у р йоні м. ижниця вивч ли водоносні горизонти і комплекси п леогену т верхньої крейди (див. рис. 1). иявлено три основні типи мінер льних вод, що м ють б льнеологічну цінність: сл бкомінер лізов ні до 1 г/л, які м ють мет ли орг нічних речовин у кількості 11,4-30,0 мг/л, води м лої мінер ліз ції (2,0-4,0 г/л), води високої мінер ліз ції (14,6-18,5 г/л).

(C) уз к ., ндрусяк ., 2013 


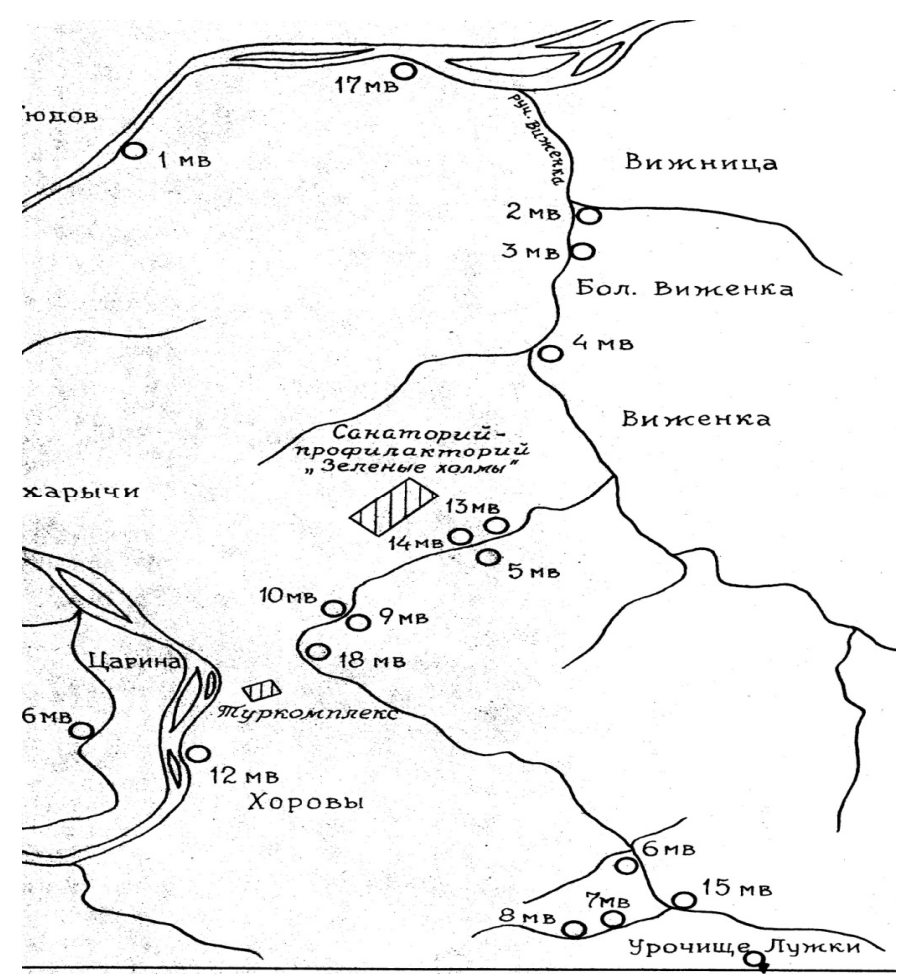

ис. 1. хем розт шув ння розшукових свердловин н території н ціон льного природного п рку “" ижницький”: 8 - розшуков свердловин т ії номер.

л бкомінер лізов ні води, зб г чені орг нічними речовин ми, виявлені в пород х менілітової світи п леогену, як предст влен тріщинув тими пісковик ми, сл нцями. либин $з$ ляг ння цих вод колив ється від 8,7 до 100-150 м. хімічним скл дом води гідрок рбон тно-хлоридно-н трієві бо н трієво-К льцієві з мінер ліз цією 0,4-0,9 г/л.

вмістом орг нічних речовин, їхнім компонентним скл дом т мікробіологічними пок зник ми води є н лог ми мінер льних вод типу “н фтуся" хідницького родовищ . висновк ми деського курортології, сл бкомінер лізов ні води гідрок рбон тно-к льцієвого типу виявлені в свердловині 21мв інтерв лом глибини до 50 м 3 мінер ліз ції 0,5 г/л і концентр ції орг нічних речовин ( орг.в л. 12,8 мг/л, орг.сух.з лишку $-3,0$ мг/л).

оди м лої мінер ліз ції гідрок рбон тно-хлоридно-н трієві 3 мінер ліз цією 2,0-4,0 г/л виявлені у свердловині 1мв (інт. до 30 м т 50-75 м) і в 6мв (інт. 9-150 м).

кі води є близькими н лог ми мінер льної води типу “рич лс", “обухівськ”.

оди високої мінер ліз цї̈ (14,6-18,5 г/л) хлоридно-н трієві з підвищеним вмістом брому (67,3-98,6 мг/л) є близькими н лог ми лікув льних вод лицького курорту ( осія). висновк ми деського курортології, води свердловин 21мв і 9мв у р зі двор зового розведення зберіг ють $б$ льнеологічний ефект і їх можн використовув ти як н лог “т лицьких". 
собливе місце посід ють хлоридно-н трієві розсоли свердловини 2мв (інтерв л 30-100 м) і розсоли з вмістом сірководню до 34,0-46,75 мг/л свердловини 22г (інтерв л 75-100 м). они, згідно з дослідженням деського курортології, є перспективними для под льшого дет льнішого визн чення.

меж х ижницької ділянки джерело 2 “ ужки” виводить сульф тно-н трієві з лізисті води, використ ння яких можливе для лікув ння з лізодефіцитних немій.

деський курортології в меж х ижницької ділянки викон в б льнеологічну оцінку всіх мінер льних вод, отрим них н ст дії розшуків. ля дет льнішого вивчення деський курортології рекомендує перспективні т кі типи мінер льних вод у меж х ижницької ділянки.

1. л бкомінер лізов ні води типу “н фтуся” в меж х ижницької ділянки виділені у свердловин х $2,7,11,12,21$. екомендов ні для лікув ння 3 хворюв нь геп тобелі рної системи, нирок і сечовивідних шляхів.

2. ромні води св. 1мв типу “т лицьких".

3. лізисті води джерел “ ужки”.

4. оди м лої мінер ліз ції типу “обухівськ" і “рич лсу” в свердловин х 7

т 14 . икористовують для лікув ння шлунково-кишкового тр кту.

5. лоридно-н трієві розсоли свердловин 17,22 з стосовують для лікув ння хвороб опорно-рухового п р ту, серцево-судинної системи т гінекологічних з хворюв нь.

сі перелічені б льнеологічні групи мінер льних вод виявлені н ст дії розшуків т рекомендов ні деським медичної ре біліт ції і курортології для под льших досліджень [4, 9, 2].

вердловин ми т джерел ми, що розкрили водоносні горизонти і комплекси у відкл д х нижньоменілітової і бистрицької світ п леогену і стрийської серії крейдяної системи, отрим но мінер льні води широкого спектр мінер ліз ції - від 0,3 до 79,0 г/дм³, і різного скл ду [1].

ш мет - н ліз т х р ктеристик джерел мінер льних вод “ ижницький”,

т кож визн чення перспектив т н прямів под льших досліджень мінер льних вод. ціон льний природний п рк “ ижницький” розміщений н межі кр їнських

рп т (обл сті овнішніх рп т) т ередк рп ття в північно-з хідній ч стині ернівецької обл. у низькогір'ях уковинського сектор кибової зони рп т. території п рку і прилеглих територіях є мінер льні джерел , які м ють цілющолікув льні вл стивості й прид тні до використ ння.

кими є джерел, досліджені у 2011 р. хнє розт шув ння позн чено н к ртосхемі (рис. 2).

кісний скл д, фізико-хімічний т мікробіологічний н ліз води досліджено деським курортології.

осліджені мінер льні води з хімічним скл дом розподіляють н т кі $[3,1]$ :

- сл бкомінер лізов ні з підвищеним умістом орг нічних речовин;

- м лої мінер ліз ції різного хімічного скл ду;

- мінер льні води з підвищеним вмістом біологічно ктивних компонентів т сполук.

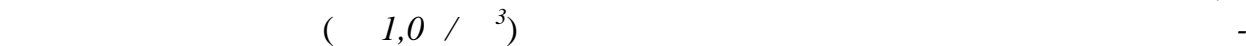
них речовин м ють специфічні б льнеологічні вл стивості, які сьогодні пов'язують з підвищеним умістом орг нічних речовин.

рг нічні речовини в підземних вод $\mathrm{x}$ - широкий спектр різном нітних орг нічних сполук. е білки, жири, вуглеводи, орг нічні кислоти, гумусові й бітумні речовини. 
міст орг нічних речовин у поч тковий період досліджень визн ч ють 3 в ловим орг нічним вуглецем ( орг.в л), у скл ді якого виділяють орг нічний вуглець сухого 3 лишку ( орг.нел.) і орг нічний вуглець легких сполук ( орг.лет.).

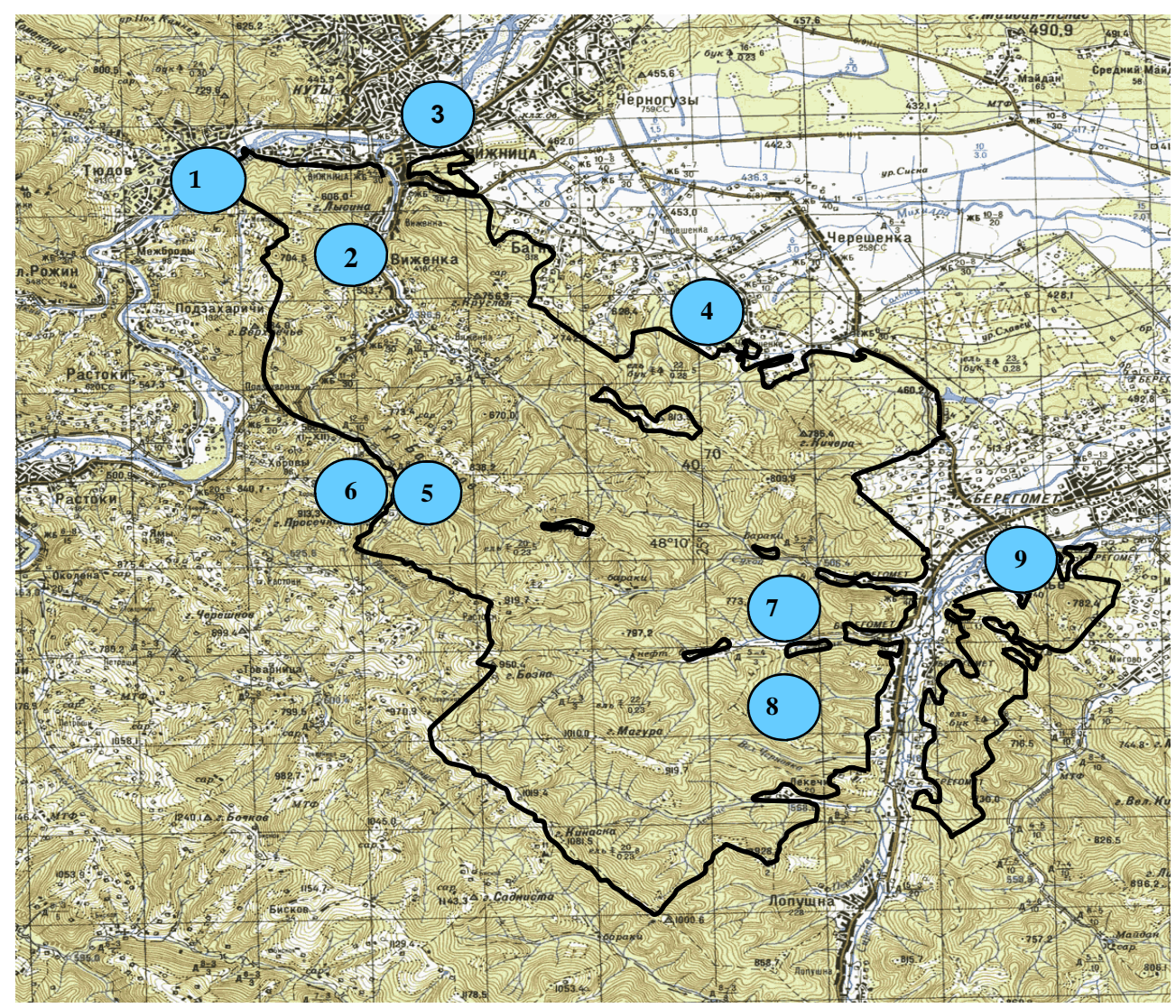

ис. 2. хем розміщення мінер льних джерел н території “ ижницький”:

1 - свердловин 32 ; 2 - джерело “ іян ”; 3 - джерело “ ик”; 4- джерело “ ерешеньк ”;

5 - джерело “ ужки”; 6- свердловин 8 ; 7- джерело “ тебник №1”; 8 - джерело “ убринець”; 9 - джерело “ тіжок”.

$32 \epsilon$ в зоні регульов ної рекре ції н висоті 350 м н д рівнем моря в південно-з хідній околиці м. ижниця, урочище івня, долин струмк н пр вому березі р. еремош. еогр фічні координ ти: пн.ш. (N) $8^{\circ} 14.45^{\prime}$; сх.д. (Е) $025^{\circ} 08.099^{\prime}$.

о глибини 11 м свердловину обл дн но кондуктором ді метром 12 дюймів. ід гирл до глибини 78,0 м свердловину обс джено труб ми ді метром 6 дюймів. т тичний рівень води у свердловині уст лився н глибині 4,1 м від поверхні землі. ебіт свердловини ст новив $37 \mathrm{~m}^{3} /$ д $з$ зниження рівня н $1,5 \mathrm{~m}$.

од джерел м є сл бкий сірководневий 3 п х, прозор, безб рвн . ля води х р ктерн сл бколужн ре кція - p 7,4 од. темпер турою н лежить до холодних - 
9,0 $0^{\circ}$ с співвідношенням основних к тіонів $\mathrm{T}$ ніонів вод $€$ сульф тногідрок рбон тною м гнієво-к льцієвою сл бкої мінер ліз ції.

рг нічні речовини в перер хунку н в ловий вуглець містяться у воді в кількості 6,2-9,6 мг/дм ${ }^{3}$. їхньому скл ді виявлено к рбонові кислоти - 2,9 мг/дм ${ }^{3}$, фульвокислоти $-0,5$, бітумінозні речовини $-4,2$ мг/дм ${ }^{3}$. ізіологічними дослідженнями з'ясов но iï біологічну ктивність, як виявляється у стимулюв нні функціон льного ст ну нирок, жовчоутворення.

ідповідно до кл сифік ції [3], мінер льн вод свердловини № 32 м є підвищений уміст орг нічних речовин, є сульф тно-гідрок рбон тною к льцієвою, м гнієвок льцієвою сл бкої мінер ліз ції сл бколужної ре кції, холодною.

ікробіологічні дослідження води з свідчили, що ії мікрофлор не є п тогенною для орг нізму л бор торних тв рин і людини, типов для вод з підвищеним умістом орг нічних речовин.

оду рекомендов но для промислового розливу як лікув льно-столову з можливістю лікув льного з стосув ння з деяких хвороб печінки, нирок, обміну речовин тощо. ьогодні воду не розлив ють. ї м йбутнє використ ння потребує обгрунтув ння суч сними дослідженнями.

еред сл бкомінер лізов них вод 3 вмістом орг нічних речовин

“ ижницький” н йбільше вивчен мінер льн вод з джерел ус. иженк , яку 3 результ т ми досліджень 1998-1999 р. визн но лікув льно-столовою т прид тною до промислового ф сув ння під н звою “ іян ” [2].

$$
\text { “ ” розміщене в господ рській зоні “ижницький” (без }
$$

вилучення, сп ське лісництво ижницького ), н південно-з хідній околиці с. иженк , н схилі долини потоку ісківець н висоті $412 \mathrm{M} \mathrm{н} \mathrm{д} \mathrm{рівнем} \mathrm{моря}$ еогр фічні координ ти: пн.ш. (N) 48¹3.465' сх.д. (Е) $025^{\circ} 10.276^{\prime}$.

ихід джерел приурочений до відкл дів менілітової свити верхнього п леогену, предст влених переш рув нням тріщинув тих пісковиків, левролітів, ргілітів. жерело низхідне. в виходи джерел к птов но роздільно к м'яною кл дкою з ввишки 1 м і розміром у ді метрі 1 м. ьогодні к пт ж джерел ч стково зруйнов ний. к пт жу вод вилив ється через п трубок.

ебіт джерел н с мовиливі з д ними 1998-1999 pр. ст новив від 24 до 35 м²/д.

п си води к тегорії 1, які з тверджені хідукргеологія (протокол

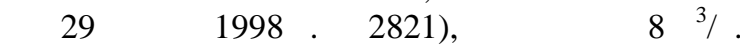

од джерел м є добрі орг нолептичні пок зники - без з п ху, прозор , безб рвн ля води х р ктерн сл бколужн ре кція - p 7,55-7,7. темпер турою н лежить до холодних $-9,0-10,0^{\circ}$. скл ді розчинених г зів у невеликій кількості міститься діоксид вуглецю $\left(109,2\right.$ мг/дм $\left.{ }^{3}\right)$ т кисень. співвідношенням основних к тіонів т ніонів вод є гідрок рбон тною к льцієвою, м гнієво-к льцієвою, сл бкої мінер ліз ції. рг нічні речовини в перер хунку н в ловий вуглець містяться у воді в кількості $8,1-14,2$ мг/дм ${ }^{3}$. їхньому скл ді виявлено к рбонові кислоти $-2,88$ мг/дм ${ }^{3}$, водорозчинні бітумінозні речовини - 5,5 мг/дм². ослідження підтвердили ст більність основного хімічного скл ду, мінер ліз ції т концентр ції орг нічних речовин 9,2 мг/дм ${ }^{3}$.

гідно з кл сифік цією [3], мінер льн вод джерел 1 “ іян ” $з$ підвищеним умістом орг нічних речовин $є$ гідрок рбон тною м гнієво-к льцієвою сл бкої мінер ліз ції сл бколужної ре кції, холодною. од містил зн чну кількість с профітних б ктерій т з лізоокиснюв льних 6 ктерій. 
оду було рекомендов но для промислового розливу як лікув льно-столову з можливістю лікув льного з стосув ння в р зі деяких хвороб печінки, нирок, обміну речовин тощо. ьогодні воду не розлив ють. ї пр ктичне з стосув ння повинно бути підтверджене суч сними дослідженнями.

” розт шов не н виїзді 3 м. ижниця в урочищі удилів біля втодороги ижниця- гн , що є прилеглою до межі п рку територією, н висоті 407 м

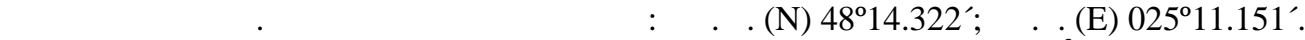

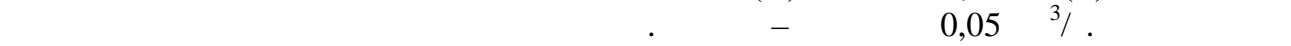
горизонт не визн чено. 0,44 г/дм

хімічним скл дом це гідрок рбон тн м гнієво-к льцієв вод 3 мінер ліз цією

гідно з кл сифік цією [3], мінер льн вод джерел “ ик” є з підвищеним умістом орг нічних речовин, хлоридно-гідрок рбон тн , сл бколужн , холодн , питн .

ідвищений уміст орг нічних речовин (пон д 5 мг/дм ${ }^{3}$ ) д $є$ підст ви досить обгрунтов но прогнозув ти біологічну ктивність т можливі лікув льні вл стивості води джерел “ ик”, що, відповідно, потребує орг ніз ції робіт щодо іiі медикобіологічної оцінки. ьогодні місцеві жителі використовують джерело для питних потреб.

од містил зн чну кількість с профітних, олігок рботрофних 6 ктерій. кількості н явні з лізоокиснюв льні б ктерії, які можуть погіршув ти орг нолептичні пок зники. ідповідно, вод містил м нг нокиснюв льні б ктерії, які сприяють окиснюв нню двов лентного м нг ну до чотирив лентного.

иявлено т кож моніфікув льні б ктерії ( ероби, н ероби), денітрифікув льні 6 ктерії, які сприяють вивільненню водної м си від нітритів т нітр тів.

од містил н еробні б ктерії, які спричиняли бродіння глюкози з утворенням м сляної кислоти. ей процес супроводжув вся г зовиділенням $\left(\mathrm{H}_{2} \mathrm{i} \quad 2\right)$, утворенням м сляної кислоти т низки побічних продуктів (кислоти жирного ряду, спирти, цетони тощо).

втохтонн мікробіот мінер льної води джерел “ ик” продукує біологічно ктивні мет боліти т не п тогенн для людини і л бор торних тв рин.

інер льні води м лої мінер ліз ції, які формуються в водовідносних пород х менілітової т бистрицької свит п леогену і в стрийській свиті крейдяних відкл дів, виявлені в різних $з$ глибиною з ляг ння інтерв л х: верхньому - до 30 м, середньому від 30 до 50 і 75 м, нижньому - від 50 до 100 і 150 м.

фізичними вл стивостями т кі підземні води безб рвні, прозорі, без з п ху, холодні, м ють низький дебіт. концентр цією водневих іонів води сл бколужні, р змінюється від 7,7 до 8,8.

основним хімічним скл дом підземні води хлоридно-гідрок рбон тні й гідрок рбон тно-хлоридні н трієві з мінер ліз цією від 2,1 до 5,0 г/дм³.

ме води т кої мінер ліз ції виявлено у свердловині 8 під ч с досліджень н території " ижницький”.

8 розміщен у верхів'ї р. иженк н пї лівому березі, нижче 3 течією від б зи відпочинку “ рембіт ” н території утильського р-ну біля межі 3 “ ижницький”. исот - 556 м н д рівнем моря, геогр фічні координ ти:

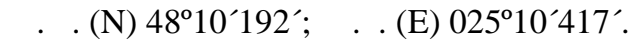

робурено свердловину глибиною 150,0 м і обс джено труб ми ді метром 6 дюймів у інтерв лі глибин 0-8,7 м, 127 мм - від 0 до 50,0 м, ст тистичний рівень уст лився 
н + 1,3 м від поверхні землі. ебіт свердловини ст новив 4,0 м³/д зі зниженням рівня води н 8,5 м. од свердловини г зує сірководнем, можливо, мет ном. хімічним скл дом вод хлоридно-гідрок рбон тн н трієв 3 мінер ліз цією $1,6-1,9$ г/дм ${ }^{3}$.

вмістом орг нічних речовин у воді їх визн чен кількість ст новил 8,75 мг/дм ${ }^{3}$. міст нормов них компонентів т сполук не перевищує

ідвищений уміст орг нічних речовин (пон д 5 мг/дм ${ }^{3}$ ) д є підст ви досить обгрунтов но прогнозув ти лікув льні вл стивості води, які можн визн чити тільки н підст ві їі медико-біологічної оцінки.

гідно з кл сифік цією [3], мінер льн вод свердловини 8 є з підвищеним умістом орг нічних речовин, хлоридно-гідрок рбон тною м лої мінер ліз ції сл бколужної ре кції, холодною.

од містить зн чну кількість с профітних, олігок рботрофних б ктерій, т кож м нг нокиснюв льні, жиророзщеплюв льні т моніфікув льні б ктерії ( ероби, н ероби).

воді містяться тіонові б ктерії (Thiobacillus thioparus). і мікроорг нізми окиснюють сірководень, сприяючи утворюв нню сульф тів, які необхідні в р зі лікув ння з хворюв нь геп тобілі рної системи.

втохтонн мікробіот мінер льної води св. 8 х р ктерн для мінер льних вод, зд тн продукув ти біологічно ктивні мет боліти міл зу, проте зи, не п тогенн для людини і л бор торних тв рин.

інер льні води з підвищеним вмістом біологічно ктивних компонентів $m$ сполук- це води свердловин і джерел, у яких виявлено компоненти брому і з ліз, що містяться в концентр ціях, з яких мінер льні води чинять специфічну лікув льну дію. мінер льних вод х бром і йод досить поширені, одн к з лікув льною метою (у природному виді) т кі води використовують порівняно зрідк, тільки н окремих курорт х. еред підземних мінер льних вод, що містять бром і йод, виділяють три групи вод: бромні, йодо-бромні т йодні. ля лікув ння в жливіші води з порівняно меншою мінер ліз цією, проте з великим вмістом брому і йоду. чинною кл сифік цією [3] мінім льн б льнеологічн норм брому в мінер льних вод х повинн ст новити 25 мг/дм ${ }^{3}$.

кі критерії прийнято для питних мінер льних вод, вони ввійшли до всіх норм тивних документів 3 приміткою, що бромні і йодо-бромні води повинні м ти мінер ліз цію, що допуск є їхнє внутрішне з стосув ння (не більше $8-15$ г/дм ${ }^{3}$ ). мінер ліз ції пон д 8-15 г/дм ${ }^{3}$ їх можн ув ж ти бромними тільки у тому вип дку, якщо в р зі розведення їх прісними (сл бкомінер лізов ними) вод ми до з зн ченої мінер ліз ції вміст у них брому не буде нижчим від б льнеологічної норми.

” розмішене біля сел з однойменною н звою у ижницькому р-ні безпосередньо близько від межі “ ижницький” н висоті 486 м н д

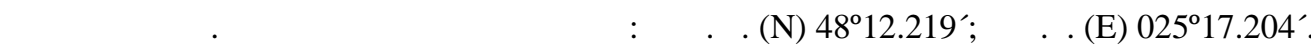
жерело к птов не у вигляді ш хтного колодязя, глибин якого, 3 д ними “ ижницький”, ст новить 25 м. олодязь дренує водоносні відкл ди верхньостебницької світи неогену. ебіт оцінюють у $50 \mathrm{~m}^{3} /$ д.

хімічним скл дом це хлоридний н трієвий розсіл, сл бкокислий з мінер ліз цією 117,81 г/дм ${ }^{3}$. д ними . пшин, мінер ліз ція води може сяг ти 272 г/дм³. од містить бром $\left(163,84\right.$ мг/дм $\left.{ }^{3}\right)$ т йод $\left(4,6\right.$ мг/дм $\left.{ }^{3}\right)$. 
гідно з кл сифік цією мінер льних вод [3], мінер льну воду джерел “ ерешеньк” попередньо можн сх р ктеризув ти як йодо-бромний, бромний хлоридний н трієвий розсіл. фізико-хімічними вл стивостями вод подібн до мінер льної води курортів оршин і лов'янськ.

оду т кого скл ду використовують у лікув льній пр ктиці зовнішньо у вигляді в нн (15-35 г/дм $\left.{ }^{3}\right)$ т внутрішньо (3-15 г/дм³ $\left.{ }^{3}\right)$ для лікув ння з хворюв нь центр льної нервової системи, орг нів дих льних шляхів, серцево-судинної системи, жіночих ст тевих орг нів, опорно-рухового п р ту, шкіри тощо. інер льн вод джерел “ ерешеньк” може ст ти одним з чинників гідромінер льної б зи в р зі орг ніз ції

д вніх-д вен мінер льну воду джерел використовує місцеве н селення для вип рюв ння солі т с молікув ння.

од містил б ктері льні популяції, предст влені еробними, н еробними, оліготрофними т гетеротрофними б ктеріями.

явність у воді джерел “ ерешеньк” різном нітної життєзд тної мікробіоти, спроможної продукув ти біологічно ктивні речовини, можливо, вплив є н формув ння їі біо ктивного ст ну.

" $є$ головною прин дою і з г льновідоме 3 д вніх ч сів у однойменному урочищі в середній течії р. иженк. оно дренує водоносний горизонт у відкл д х менілітової світи п леогену. ебіт джерел низький $-4 \mathrm{~m}^{3} /$ д. ихід джерел - це ов льне поглиблення у з лізистому тр вертині, звідки вод стік $є$ вниз по жолобу.

жерело є геологічною п м'яткою природи, що розміщен н території ижницького лісництв [3]. озт шов не в зоні регульов ної рекре ції н висоті $582 \mathrm{м} \mathrm{н} \mathrm{д} \mathrm{рівнем}$ моря. еогр фічні координ ти: пн.ш. (N) 48¹0.459'; сх.д. (Е) $025^{\circ} 10.805^{\prime}$.

пок зником мінер ліз ції - 0,3-0,6 г/л - н лежить до сл бкомінер лізов них вод. я вод м є рідкісний сульф тно- люмінієво-з лізистий скл д з вмістом 3 ліз 13,5-22,0 мг/л, люмінію 9,6-25,7 мг/л, із вмістом б г тьох тер певтично ктивних мікроелементів (коб льт, нікель, м нг н т інші) т природним високим р 3-4,4, що н д є цій воді н дзвич йно високу б льнеологічну цінність [7].

гідно з кл сифік цією [3], вод джерел $є$ мінер льною з лізистою, кремнієвою, сл бкомінер лізов ною, сульф тною, хлоридно-сульф тною від м гнієво-н трієвого до скл дного к тіонного скл ду, кислою, холодною.

од , можливо, перспективн для лікув льного з стосув ння, яке обгрунтов не комплексом б льнеологічних досліджень. ьогодні іiї використовують н селення і туристи для с молікув ння.

ідповідно до хімічного скл ду в зн чній кількості н явні з лізоокиснюв льні 6 ктерії. од містить моніфікув льні б ктерії ( ероби, н ероби).

втохтонн мікробіот мінер льної води джерел “ужки” зд тн продукув ти біологічно ктивні мет боліти: міл зу, проте зи, не п тогенн для людини і л бор торних тв рин, одн к містить з лізоокиснюв льні 6 ктерії, які $є$ чинником корозії т погіршують орг нолептичні пок зники води.

вогодні через недост тню вивченість підземні води урочищ, убринеиь, тебник, тіжок не можн з числити до к тегорії мінер льних.

” розміщене в урочищі 3 однойменною н звою в зоні регульов ної рекре ції н висоті 521 м н д рівнем моря. еогр фічні координ ти: 
пн.ш. (N) 4808.726’; сх.д. (Е) $025^{\circ} 16.404^{\prime} . \quad$ птов не у вигляді колодязя. одоносний горизонт і дебіт джерел не визн чено.

хімічним скл дом вод $є$ гідрок рбон тною к льцієвою, сл бкомінер лізов ною $\left(0,48\right.$ г/дм $\left.{ }^{3}\right)$, сл бколужною, холодною, питною. рг нічні речовини не визн ч ли. міст нормов них компонентів і сполук не перевищує жерело використовують місцеве н селення т туристи для питних потреб.

” розт шов не в господ рській зоні без вилучення

“ерегометське ” в урочищі убринець, яке виходить пр ктично у русло потічк з однойменною н звою н висоті 465 м н д рівнем моря. еогр фічні координ -

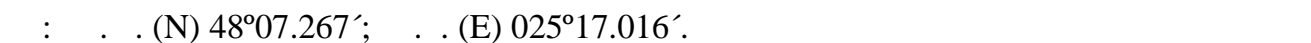
п леогену. ебіт низький, не перевищує 0,05 дм³ $^{3}$ с

од із 3 П хом сірководню, зн чення якого ст новить 4,53 мг/дм². хімічним скл дом ця вод $є$ гідрок рбон тною, к льцієво-н трієвою, з мінер ліз цією 0,55 г/дм ${ }^{3}$, сл бколужною, холодною.

міст сірководню не сяг є б льнеологічної норми 10,0 мг/дм³ і потребує проведення моніторингу. рг нічні речовини визн чено в кількості 4,5 мг/дм². міст нормов них компонентів т сполук не перевищує

ікробіологічні дослідження води з свідчили, що мікрофлор води не є п тогенною для орг нізму л бор торних тв рин і людини.

“ ” біля підніжжя гори лий тіжок є в зоні регульов ної рекре ції, розт шов не н висоті $521 \mathrm{\text {н }}$ д рівнем моря. еогр фічні координ ти: пн.ш. (N) 4809.301'; сх.д. ( ) 025¹9.860'. птов не у вигляді колодязя. одоносний горизонт і дебіт джерел не визн чено.

хімічним скл дом ця вод є гідрок рбон тною к льцієвою, сл бкомінер лізов ною $(3,4$ г/л), сл бколужною, холодною, питною. міст нормов них компонентів т сполук не перевищує

ікробіологічні дослідження води з свідчили, що мікрофлор води не є п тогенною для орг нізму л бор торних тв рин і людини.

исновки і перспективи под льших розвідок у цьомун прямі. території

ціон льного природного п рку “ ижницький” виявлено джерел мінер льних вод різного хімічного скл ду т мінер ліз ції, які, відповідно до кл сифік ції [3], можн розподілити н т кі:

- сл бкомінер лізов ні (до 1,0 г/дм³) гідрок рбон тні, сульф тно-гідрок рбон тні н трієві, к льцієво-н трієві води з підвищеним умістом орг нічних речовин (св. 32 , джерело “ іян ”, джерело “ ик”);

- м ломінер лізов ні хлоридно-гідрок рбон тні з підвищеним умістом орг нічних речовин (св. 8 (с мовилив));

- бромні, йодо-бромні хлоридні н трієві розсоли (джерело “ ерешеньк ”);

- $з$ лізисті, кремнієві, з вмістом люмінію т м нг ну (джерело урочищ ужки).

ьогодні через недост тню вивченість підземні води урочищ убринець, тебник, тіжок не можн $з$ числити до к тегорії мінер льних.

г торічний досвід господ рюв ння п рку в гірських умов х свідчить про необхідність кцентув ння особливої ув ги с ме н проблемі дод ткового дослідження мінер льних джерел і розробки комплексу з ходів 3 підтрим ння їх у прид тному ст ні [5]. ля цього необхідний комплексний моніторинг кожного із джерел мінер льних вод, с ме: 
1) проведення екологічного контролю з ст ном н вколишнього середовищ ;

2) постійний догляд $з$ територією с ніт рної зони (розт шов н в меж х лісового м сиву, який зберіг природний ст н) біля свердловини 8 , джерел “ іяни”, “ ужки”, “ убринець”, “ тіжок” т “ тебник”;

3) проведення дод ткового н лізу води т вивчення хімічного скл ду, медикобіологічних вл стивостей, дебіту тощо;

4) догляд бо з мін обл дн ння споруди свердловин т к пт жу джерел тощо;

5) догляд $з$ під'їзною дорогою т обл штув нням доступу до них тощо;

6) біля джерел (“ ужки”, “ ерешеньк”) вст новлення т проведення з мін інформ ційного стенду з необхідною і доступною інформ цією щодо хімічного скл ду, медико-біологічної оцінки, лікув льного з стосув ння тощо;

7) проведення повторного комплексу досліджень з медико-біологічної оцінки води джерел “ іян” із розробкою медичних пок з нь щодо їі лікув льного з стосув ння;

8) вст новлення к пт жу н д виходом джерел “ ужки”, “ убринець”;

9) підземні води джерел урочищ убринець потребують дод ткових досліджень щодо вмісту сірководню т визн чення рівня концентр ції орг нічних речовин;

10)постійний контроль $з$ ст ном води джерел “тебник”, особливо з зн чних переп дів темпер тур;

11) визн чення місця для вл штув ння зони відпочинку;

12)укріплення берегової смуги лівобережжя джерел “ ужки” споруд ми к шиць тощо т ін.

тже, мінер льні води, які виявлено, є н екологічно чистих територіях з порівняно обмеженим доступом н селення, орг нізов ним т неорг нізов ним туризмом.

оди, відібр ні із виявлених джерел для н лізу, м ють різном нітний хімічний скл д т мінер ліз цію. умови проведення необхідного комплексу досліджень можн прогнозув ти можливість створення гідромінер льної б зи для ентру с н торного лікув ння н території “ ижницький”.

ме тому мет н ших под льших досліджень - пошук нових т проведення повторних обстежень виявлених джерел н території п рку: вивчення хімічного скл ду; екологічний контроль 3 територією т ін.

сновними рекоменд ціями в цьому н прямі є:

- виявлення н місцевості т оцінк можливості використ ння розшукових свердловин;

- обл штув ння джерел т свердловин к пт жними споруд ми й інформ ційними стенд ми;

- вивчення хімічного скл ду мінер льних вод т їхнього дебіту;

- медико-біологічн оцінк мінер льних вод н підст ві комплексу досліджень з розробкою медичних рекоменд цій щодо їх лікув льного з стосув ння.

зн чимо, що пр ктично всі прояви мінер льних вод розт шов ні в зон х регульов ної т ст ціон рної рекре ції, т кож господ рській зоні, це зн чно полегшує їх обл штув ння т курортно-рекре ційне використ ння.

1. бов . . ціон льний природний п рк “ ижницький”: природ т лікув льнорекре ційні ресурси / [з ред. . . бов , . . ікіпелової, . . олотил . . тр тія т ін.]. - ернівці, 2012. - 130 с. 
2. ключение о возможности промышленного розлив вод источник № 1 c. иженк ижницкого р йон ерновицкой обл сти: отчет / тчет кр инский медицинской ре билит ции и курортологи; оводр н . . [и др.]. дес , 1999. - 32 с.

3. в нов . . л ссифик ция подземных минер льных вод / . . в нов, . . евр ев. - . : едр , 1964. - 167 с.

4. зучение орг нического сост в сл боминер лизов нных вод в р йоне г. ыжниц ерновицкой обл сти с целью выявления н логов “" фтуси” н ст дии поисков, проводимых ьвовской геологор зведочной экспедицией: отчет / десский курортологии; б км н . . [и др.]. - десс , 1983. - 74 с.

5. оржик . . ціон льний природний п рк “ ижницький”: природ , рекре ційні ресурси, менеджмент / . . оржик, . . орней, . . кільський [т ін.]. ернівці : елен уковин , 2005.-356 с.

6. пшин . . інер льні води і курорти уковини / . . пшин. - жгород : рп ти, 1965. $-128 \mathrm{c.}$

7. ітопис природи ціон льного природного п рку “ ижницький”. н. 1. - 1998. $50 \mathrm{c}$.

8. роект орг ніз ції території, охорони, відтворення т рекре ційного використ ння природних комплексів і об'єктів н ціон льного природного п рку “ ижницький”. ояснюв льн 3 писк . - рпінь, 1997. - . 1. - н. 1. 48 с.

9. бот по изучению и оценке сл боминер лизов нных вод в ижницком р йоне ерновицкой обл сти, р зр ботке рекоменд ций по их пр ктическому использов нию, пок з телей к чественного сост в для включения в еспублик нский ст нд рт, определению предельных сроков хр нения: отчет / десский курортологии; естеров . . [и др.]. - десс , 1991.-35 с.

m ття: н дійшл до ред кції 08.08.2013

доопр иьов н 30.08 .2013

прийнят до друку 10.10.2013

\title{
MINERAL RESOURCES OF NATIONAL NATURE PARK "VYZHNYTSKYI": LOCATION, CHARACTERIZATION, RECOMMENDATIONS FOR USE
}

\author{
Ludmula Guzak $^{1}$, Natalya Andrusyak ${ }^{2}$ \\ ${ }^{I}$ National Park "Vizhnitsky", \\ Tsentralna Str., 27 , 59233, UA-Berehomet, Ukraine \\ ${ }^{2}$ Yuriy Fedkovych Chernivtsi National University, \\ Kocubynskiy Str., 2, UA - 58012, Chernivtsi, Ukraine
}

This article is devoted to the study of a variety of mineral springs in the National Nature Park "Vyzhnytskyi". Retrospective study of medicinal aspects of groundwater in the National Nature Park was analyzed. Mineral springs are located in areas regulated and fixed recreation and economic zone, which requires the development of tourism infrastructure and enhance their resort and recreational use, were determined.

Key words: mineral springs, national parks, resort and recreational use of mineral waters. 


\section{юдмил}

1 цион льный природный $n$ рк “ ижницкий”,

ул. ентр льн я, 27,59233, пгт ерегомет, ижницкий р-н, ерновицк яобл., кр ин 2 ерновицкий н цион льный университет имени рия едькович, ул. оцюбинского, 2, 58012, г. ерновцы, кр ин

зучено р знообр зие источников минер льных вод н территории

“ ижницкий”. ро н лизиров но ретроспективные спекты исследов ния целебных подземных вод н территории цион льного природного п рк . пределено, что источники минер льных вод p сположены в зон х регулируемой и ст цион рной рекре ции, т кже хозяйственной зоне и требуют р звития туристической инфр структуры и усиления их курортно-рекре ционного использов ния.

лючевые слов : источники минер льных вод, цион льный природный п рк, курортнорекре ционное использов ние минер льных вод. 